\title{
THE EFFECT OF BRAND IN TRUST, SERVICE QUALITY, PROMOTION MIX ON CUSTOMER SATISFACTION
}

\author{
(CASE STUDY ON PT. INDOLOK BAKTI UTAMA BRANCH OF MATARAM)
}

\author{
Baiq Rika Minarti Sari Dewi ${ }^{1}$, Dwi Putra Buana $S^{2}$, Handry Sudiartha $A^{3}$ \\ ${ }^{1}$ Student at Faculty of Economics and Business, Master of Management Program, \\ University of Mataram. E-mail: baiqrikaminarti@gmail.com \\ ${ }^{2}$ Faculty of Economics and Business, \\ University of Mataram, Indonesia. E-mail: dwiputrabs39@gmail.com \\ ${ }^{3}$ Faculty of Economics and Business, \\ University of Mataram, Indonesia. E-mail: andre_sudiartha@yahoo.com \\ DOI: $10.31364 / S C I R J / v 7.18 .2019 . P 0819688$ \\ http://dx.doi.org/10.31364/SCIRJ/v7.i8.2019.P0819688
}

\begin{abstract}
PT. Indolok Bakti Utama is one of the pioneers in fire-fighting and security products in Indonesia, especially in NTB. The phenomenon faced by PT. Indolok Bakti Utama Mataram is in the period 2012-2015 the company's sales tend to fluctuate. This study aimed to identify and analyze the effect of Brand in Trust to customer satisfaction, to know and analyze the effect of service quality on customer satisfaction and to know and analyze the influence Promotion Mix against Customer Satisfaction. The population in this study are all consumers of PT. Indolok Bakti Utama, with the sample, are 100 peoples. Data analysis used by multiple regression. The results showed that Brand In Trust has a positive and significant impact on customer satisfaction, Promotion Mix has a positive and significant impact on customer satisfaction and service quality has a positive and significant impact on customer satisfaction.
\end{abstract}

Keyword: Brand In Trust, Service Quality, Promotion Mix, Customer Satisfaction

\section{PRELIMINARY}

\subsection{Background}

The business world is now faced with an increasingly competitive pesaingan rapid almost no exception in all areas of business in industri.Untuk continue to survive and become a winner, every company is required to continue to make a creative and innovative strategies in line with the demands of consumer needs and desires of an increasingly complex and tend to change dynamically over time. In anticipation of these issues, each company is required to have the sensitivity to understand any changes that occur, and focuses on the orientation of the increase in consumer confidence, quality of service and sales promotion strategies that can give satisfaction to customers today and in the future. Talking about customer satisfaction, of course, can not be separated from a variety of factors menyertainya.Trust in a brand or trust in the brand is one cause of customer satisfaction in consuming a certain brand products. Brand trust is an important factor for consumers because it helps reduce purchases uncertain. According Chaunduru Holbrook (2001) in Riana (2008), trust in the brand is the confidence associated with the reliability and integrity of the brand. Studies Delgado (2004) in Prasilowati (2005) trust in Brand is the expectation of reliability and intense brand. Previous research has been carried out by Uniyati, (2009) and Soegoto, (2013), that confidence in the brand has the most dominant influence on customer satisfaction.

In addition to trust in a brand can create customer satisfaction; the creation of quality services will also create user satisfaction with the service. The quality of these services can ultimately provide benefits, including established harmonious relationship between providers of goods and services to customers provide remuneration that, both for the creation of customer loyalty by forming a recommendation by word of mouth (word of mounth) are favorable for providers of goods and the services (Mulyono, 2008: 2). One of the five factors that can affect the level of customer satisfaction is the quality of service (Lupiyoadi, 2006: 49). Empirical studies conducted byPrevious studies conducted by Faradina and Satrio (2016), Setiawan (2014), Zain (2013), Karuntu, Christoffel, Nia, (2014), Ogi, Adolfina, and Ruusen, (2014),Sivadas and Baker-Prewitt, 2000 (in Nam, Ekinci and Whyatt 2011) quality of service has a positive relationship with satisfaction pelanggan.Penelitian Lenzun, Massie, Adare, 2014, the results of the study showed that simultaneous quality products, significant effect on customer satisfaction. Meanwhile, according to Sureshchandar et al., (2002) that there is a very close correlation between the quality of service and satisfaction pelanggan.Pelanggan will feel satisfied if they get good service or as expected. However Ekinci and Whyatt, (2011), Studies show that for consumer involvement with the category of services will occur more dominant in their influence on brand loyalty than 
satisfaction with the preferred brand. In this study, researchers were just looking for a direct relationship between the quality of service to customer satisfaction.

Meanwhile, according to Silverman (2001), a customer recommendation and promotional tools salewhich is very effective in influencing potential prospects. Consumers who are satisfied with the brand it uses will notify the advantages of the brand to others.Previous studies conducted by Faradina and Satrio (2016), Setiawan (2014), Adolfina and Ruusen (2014) Endang Tjahjaningsih (2013) promotion of positive effect on customer satisfaction. Zain (2013) promotion is the variable most dominant influence on the formation of the Customer Satisfaction. However, researchLenzun, Massie, Adare (2014) promotion of research results show significant negative effect but not on customer satisfaction.

PT. Indolok Bakti Utama is one of the pioneers in fire-fighting and security products in Indonesia, especially in this NTB.Perusahaan become one of the leading providers of products outages and security solutions, which offer a variety of products and systems to help consumers protect themselves from fire and security threats. with extensive experience, PT Indolok Bakti Utama is a reliable business partner in providing the best services related to product quality fire and security solutions for this bisnis.Perusahaan partners in naungi by a company called GUNNEBO GROUP, where the company has several manufacturing companies scattered in various countries such as Sweden, Germany and Indonesia.

In expanding the existing market share, the PT Indolok Bakti Utama also has a branch network covering 27 provinces in Indonesia and is divided into three (3) the area / region with each sub-region, Eastern Region (East Region) Central Region (Central Region ) and Western Region (West Region). One branch office located in the area east region located in Mataram, which is located on the road of Sandubaya-Sweta.

Table 1. Total products sale at PT. Indolok Bakti Utama Mataram 2012-2015

\begin{tabular}{cccc}
\hline Year & sale & $\begin{array}{c}\text { Percentage of Sales } \\
(\mathbf{\%})\end{array}$ & $\begin{array}{c}\text { Units Sold } \\
\text { products }\end{array}$ \\
\hline 2012 & Rp. 833 451 496 & 17,18 & 45 \\
2013 & Rp. 842057 975 & 17.35 & 65 \\
2014 & Rp. 1223413543 & 25.20 & 255 \\
2015 & Rp. 1954897145 & 40.27 & 114 \\
total & rp, 4853820159 & $\mathbf{1 0 0}$ & $\mathbf{4 7 9}$ \\
\hline
\end{tabular}

Source: Primary Data 2016

According to the table 1 above, shows that the total sales of the product on the PT. Indolok Bakti Utama Mataram 2012 2015 tended to fluctuate. The increase in sales occurred between 2014 to 2015 is from $25.20 \%$ increase to $40.27 \%$. Likewise, the number of units involved products sold increased. The increase in sales was highest padatahun product unit in 2014 that as many as 255 products sold, an increase over the previous year which only sold 65 units. However, in 2015 the number of products sold decreased dramatically, namely to as many as 114 units.

Penelitian is done on the basis of the results of previous research gap that still inconsistent so it requires more lanjut.Seperti assessment study carried out by Susilo (2017) found that brand in trust, quality of service and promotion mix positive and significant impact on customer satisfaction. Meanwhile, research conducted by Santi (2018) brand in trust, quality of service and promotion mix has no influence on customer satisfaction.

The second reason dilakukanya this study due to a phenomenon that occurs on the object of research in which the object of study is the only provider of security control in Mataram and have never been anyone doing research, so research is expected to contribute to both the development of science in the field of marketing, for further research and for managerial PT. Indolok Bakti Utama Branch of Mataram.

\subsection{Research purposes}

The purpose of this study are:

1) To know and analyze effect of Trust In Brand influence on customer satisfaction.

2) To know and analyze effect of service quality on customer satisfaction.

3) To know and analyze influence Promotion Mix against Customer Satisfaction.

\section{LITERATURE REVIEW}

\subsection{Trust in Brand}

Confidence awakened by the hope that the other party will act in accordance with the needs and desires of consumers. When someone has to trust others so they believe that the expectations will be met and no more disappointments. According to Gefen (2002) in Prasilowati (2005) whorthness trust is a multidimensional construct that combines some certain beliefs which either directly or through a vote of confidence affecting the behavior of different intensity. Loyaliyas complete understanding of the brand can not be obtained without an explanation of trust towards the brand (trust in a brand).According to Lau and Lee (1999) in Prasilowati (2005), there are three factors that affect trust in the brand. These three factors are related to the three entities included in the relationship between brands and consumers. The third factor is the brand characteristic, company characteristic and consumer brand characteristic.

According Zaitna (2003) in Darsono (2008) trust is the desire to lean (trust) to exchange Parmer believed. In line with the above definition, the trust by Holbrook (2001) in Darsono (2008) emphasizes bahw trust only element in uncertain situations. In particular, trust reduces uncertainty in an environment in which consumers feel screwed because they know they will be able to 
lean on a trusted brand. Yi Shun Wang (2005) defines trust as a set of specific beliefs with mainly dealing with integrity (honesty and ability to keep promises or trustee), benevolence (awareness and motivation trustee to act are not the best for trusters), predictability (the consistency of behavior trustee) (Darsono 2008).

Lau and Lee (1999) in Darsono (2008) argues that the trust factor against a brand is a crucial aspect in the formation of brand loyalty. They define a trust to a brand as kesediaaan consumers to trust the brand in a situation of risk for their expectations that the brand in question will give positive results (Darsono, 2008). Factors that play an important role in shaping the trust of the brand include (Samuel, 2005):

a. Brand Predictability : brand Predictabilityrefers to the ability of customers to anticipate the performance of the brand in various usage situations. Predictability can be shaped as a result of interaction ulanlgan and consistency of the quality level of products or services. Predictability brand increased confidence because consumers know that nothing unexpected will happen when the product is used. Predictability brand will remind the confidence in the brand because the brand predictability will increase confidence in the brand because predektibilitas build positive pengahapan.

b. Brand Liking : brand Liking relating to whether a particular brand favored or not to customers

c. Brand Competence : brand Competencerefers to the ability of the brand to solve customer problems and to meet their needs. Capability refers to the skills and characteristics that allow one party to influence in a domain all mempertimbangkankemampuan as essential elements that affect the trust. Brand competence can be assessed customers through user experience of products or services directly or through community

d. Brand Reputation : brand Reputation Referring to the opinions of others that good and reliable brand in question. Brand reputation can be formed through advertising, public relations, product quality or service.

e. Trust in Company : Trust in Company The level of confidence in the company that owns the brand in question.

\subsection{Promotion}

Promotion is one of the variables contained in the marketing mix have an important role to communicate the existence and value of the customer.In designing products to prospective marketing strategy, companies should always be oriented to consumers from finding the products desired by consumers, determine the motives and habits membeliserta prices according to the purchasing power of consumers, determine the distribution channels and ultimately determine promotional program in an effort to increase sales.

According to Kotler (2005: 264), the promotion mix is a combination of five main tools consisting of advertising, personal selling, publicity, sales promotion and direct marketing. Promotion mix is the best strategy combination of variables consisting of advertising promotion, personal selling, publicity, sales promotion and direct marketing used in persuasive communication and planned to achieve sales program.

\subsection{Service Quality}

Kotler (2005) express the notion of quality as follows: "quality is the totality of features and characteristic of a product or services tha bear on its ability to statisy or implied needs". Overall quality is the hallmark of the goods and services that affect its ability to meet customer kebutuaha declared or not declared.

From the above definition can be concluded that service quality is the difference between customer expectations (expection $=\mathrm{E}$ ) with the perceived performance of customers (perceived performance $=\mathrm{P}$ ), quality of service can be said to be good if there are similarities between the expectations with the perceived performance $(\mathrm{P}=\mathrm{E})$ or the perceived performance exceeds expectations ( $\mathrm{P}>\mathrm{E}$ ). According to Parasuraman (1993), states that there are five dimensions of service quality, namely tangibles, empathy, reliability, responsiveness, and assurance (Darsono, 2008) The purpose of this service is customer satisfaction. Consumers are a very important asset and valuable to the survival of the company.

Zeithamal, Parasuraman, Berry (in Rahmulyono 2008) considers that there are indicators of size through five (5) service quality dimensions, namely:

a. Reality (tangibles): the needs of customers who focuses on goods and services, it includes the physical facilities, equipment, personnel and other means appearance.

b. Trust (reliability): namely the fulfillment of immediate and satisfactory service. Trust is a skill in delivering the promise of responding to customers. This customer already can guess or estimate the level of service quality delivered on time was first given by the company.

c. The response (responsiveness) is a policy to assist and provide fast service (responsiveness) and the right to the customer with clear information delivery.

d. Assurance (assurance) that the customer is given which includes the ability, courtesy and trustworthiness which is owned by the employees of the company and is free from risk. Security is a feeling of customers where they feel the problems that exist are in good hands, proficiency in delivering confidential personnel, have any interest or liking towards customers and demonstrate the attention and concern.

e. Security or protection (empathy) that is the ease of doing good communication and understanding of customer needs. Security is a gift to the protection, attention to the customer including listening to customers (Rahmulyono, 2008: 18).

\subsection{Customer Satisfaction}

Kotler (2005: 70) mengemukanan customer satisfaction are: The level of person 'felt state from comparing a product's perceived performance in relation to the person's expactation ". In other words, customer satisfaction is the level of one's feelings after comparing the perceived performance or results compared to expectations. Customer satisfaction or dissatisfaction of customers is the customer response to the evaluation or disconfirmation perceived discrepancy between prior expectations (or 
other performance norm) and the actual performance product that is felt after pemakaiannya.Para marketing expert defines customer satisfaction as a response to consumer behavior in the form of after-purchase evaluation of an goods or services that he felt (product performance) compared with consumer expectations. Customer satisfaction is highly dependent on customer perceptions and expectations that sendiri.Faktor the factors that affect customer perceptions and expectations when making a purchase of goods or services is the need or desire felt by the consumer when purchasing goods or services, past experience when consuming goods or services from advertising. In a competitive environment, indicators that can show customer satisfaction is whether consumers will buy back and use the product at a time when that will come (Nawawi, 2006). Factors that influence the perceptions and expectations of customers when making a purchase of goods or services is the need or desire felt by the consumer when purchasing goods or services, past experience when consuming goods or services from advertising. In a competitive environment, indicators that can show customer satisfaction is whether consumers will buy back and use the product at a time when that will come (Nawawi, 2006). Factors that influence the perceptions and expectations of customers when making a purchase of goods or services is the need or desire felt by the consumer when purchasing goods or services, past experience when consuming goods or services from advertising. In a competitive environment, indicators that can show customer satisfaction is whether consumers will buy back and use the product at a time when that will come (Nawawi, 2006).

The company's main purpose is to create customer satisfaction, but if it must reduce prices or increase their services then happens is the decrease keuntungan.Untuk know how the customer's needs without having to sacrifice profits, companies can measure customer satisfaction with several methods.

There are four methods that can be used in measuring customer satisfaction, namely (Kotler, 2005: 72):

a. Complaint suggestion system: The information obtained through this method can provide new ideas and satisfy this method can provide new ideas and satisfy extremely valuable to the company, making it possible to react with a fast and responsive in addressing the problems that arise.

b. Customer satisfaction surveyThrough survey method, the company will obtain feedback and direct feedback from consumers and also mmeberikan positive signal that the company pay attention to them.

c. Ghost shopping: Companies can pay a person to act as a potential buyer to report its findings on the strengths and weaknesses they experience in mebeli the company's products and competitors' products.

d. Last customer analysis: Companies should contact customers who stop buying or switching suppliers to learn why. In order to take further policy improvements or enhancements.

According to Haryono and Octavia (2014), Koyong et al (2016) and Prayoga (2017), the factors that affect customer satisfaction are as follows:

1. Quality of Service / Service Quality, an effort to fulfill the needs and desires of the customer and accuracy in delivery so that customers' expectations are met

2. problem Experienced, The impression received by the customer when the products or services it receives experiencing problems

3. User Friendly servce, service received by the customer can be easily accepted

4. Service Advisor, a person who provides services to the customers so that customers easily grasp and understand every detail of the product or service

5. Trust Is the conviction of the parties concerning the purpose and behavior of the other party. Belief or trust is the expectation that providers of services or products are reliable in fulfilling his promise

6. Promotion Mix, is a collection or set of marketers attempt to inform and influence other people so interested in the transaction or exchange of goods or services which it markets.

\subsection{Hypothesis}

The hypothesis of this study are as follows:

1. H1: Brand In Trust has effect on customer satisfaction at PT. Indolok Bakti Utama Branch of Mataram

2. H2: Service Quality has effect on customer satisfaction at PT. Indolok Bakti Utama Branch of Mataram

3. H3: Promotion Mix has effect on customer satisfaction at PT. Indolok Bakti Utama Branch of Mataram.

\section{METHOD RESEARCH}

This type of research is causality. The population in this study are customers of PT. Indolok Bakti Utama ever made a purchase within the last 5 years and the users who use the services after sales in the same period. The sample is partially or representative of the population studied, if researchers only wanted to examine the part of the population then his research is the study sample (Arikunto, 2006). In this study, the sample is determined by the researcher of 100 respondents, which is supported by the opinion of criteria Roscoe,

Variable trust in a brand is measured using indicators developed by Samuel (2005), the variable promotion mix is measured using indicators developed by Kotler (2012), the variable Service Quality is measured using indicators developed by Tjiptono (2012) and customer satisfaction using indicators developed by Fornell et al (1996) in Tjiptono (2012). In giving the weighting of each of the variables used a five-level scale that consists of strongly agree, agree, quite agree, disagree and strongly disagree. Validity test results of the entire instrument showed that all items on the variables being used is valid. This is because all instruments of research variables were above the value of $r=0.30$. Reliability test results also showed that all the research instrument in the category of all instruments reliable because the study showed Cronbach alpha values above 0.60 . Analysis of the data used in this research is multiple linear regression. 


\section{RESULTS RESEARCH AND DISCUSSION}

\subsection{Results of Multiple Regression Analysis}

Testing the hypothesis in this study were performed using the SPSS 16.0 to analyze the effect of brand in trust (X1), promotion mix (X2) and Service Quality (X3) against Customer Satisfaction (Y) at PT. Indolok Bakti Utama Branch of Mataram. Multiple regression model in this study is shown as follows:

Table 2. Regression Results

\begin{tabular}{|c|c|c|c|c|c|c|}
\hline & \multirow[b]{2}{*}{ Model } & \multicolumn{2}{|c|}{ Coefficients unstandardized } & \multirow{2}{*}{$\begin{array}{c}\begin{array}{c}\text { standardized } \\
\text { Coefficients }\end{array} \\
\text { beta }\end{array}$} & \multirow[b]{2}{*}{$\mathrm{t}$} & \multirow[b]{2}{*}{ Sig. } \\
\hline & & B & Std. Error & & & \\
\hline \multirow[t]{4}{*}{1} & (Constant) & 0.461 & 0.293 & & 1.575 & 0.119 \\
\hline & $\mathrm{X} 1$ & 0.404 & 0.137 & 0.371 & 2.962 & 0.004 \\
\hline & $\mathrm{X} 2$ & 0.272 & 0.097 & 0.229 & 2.795 & 0.006 \\
\hline & $\mathrm{X} 3$ & 0.547 & 0.111 & 0.530 & 4.915 & 0.000 \\
\hline
\end{tabular}

Based on Table 4.7 above, it can be formed regression equation of dependent and independent variables as follows:

$$
\begin{aligned}
& \mathrm{Y}=\alpha+\beta 1 \mathrm{X} 1+\beta 2 \beta 3 \mathrm{X} 2+\mathrm{X} 3+\mathrm{e} \\
& 0.404 \mathrm{X} 1 \mathrm{Y}=0461+0547+0272 \mathrm{X} 2+\mathrm{X3}+\mathrm{e}
\end{aligned}
$$

Where:

$\alpha=$ constant

$\mathrm{Y}=$ Customer Satisfaction

$\mathrm{X} 1=$ Brand In Trust

$\mathrm{X} 2$ = Promotion Mix

X3 = Service Quality.

Based on the multiple regression model will then be analyzed on the influence of the independent variable on the dependent variable. Interpretation of the regression model are:

Linear functions mentioned above can be described as follows.

1. Constant value of $\mathbf{0 . 4 6 1}$ means that if each independent variable has a value of 0 , then Customer satisfaction has positive value of 0461, This means that Customer satisfaction remains to be positive in the absence variables Brand In Trust, Promotion Mix and Quality Service.

2. The regression coefficient of Brand In Trust (B1) which totaled 0.404 means that when variables Brand In Trust(X1) was added to the linear regression model, thenCustomer satisfactionwill increase by 0.404 , The regression coefficient of Brand In Trust (B1) which is positive, it means that the higher Brand In Trust of consumers, customer satisfaction will be higher.

3. The regression coefficient of Promotion Mix (B2) are worth 0.272 explains that when variables Promotion Mix (X2) is inserted into the model, then Customer satisfaction increased by 0.272 , The regression coefficient of Promotion Mix (B2) which is positive, this means that the more attractive Promotion Mix then Customer satisfactionit will be higher.

4. The regression coefficient of Service Quality (B3) is 0.547 shawed that when variables Quality of Service (X2) is inserted into the model, then Customer satisfactionan increase of 0547. The regression coefficient of Service Quality (b2) which is positive, it means that the higher the Service Quality will be higher Customer satisfaction as well.

\subsection{Discussion}

\section{a. Brand In Trust Of Influence Customer satisfaction}

Based on test results obtained by the value that has been done thitung 2962 with significance level of 0.004 so that there is significant influence Brand In Trustterhadap Customer satisfaction onPT. Indolok Bakti Utama Branch of Mataram. This means that the higher the Brand In Trust the higher the consumer Customer Satisfaction at PT. Indolok Bakti Utama Branch of Mataram.Sehingga can be concluded that the first hypothesis proposed that there are significant brand in trust to customer satisfaction is acceptable.

The results support the empirical study conducted by Susilo (2017) that brand trust has a positive and significant effect on customer satisfaction. In this study Brand In Trust reflected in indicators such as Brand Predictability 5, Liking Brand, Brand Competence, Brand Reputation, Trust in Brangkas company Chubb Safes in PT. Indolok Bakti Utama Branch of Mataram. where the five indicators positive response by the respondent and are at very high category.

\section{b. Influence Promotion Mix To Customer satisfaction}

Based on the results of testing that was done found that the results of hypothesis testing variables Promotion Mix shows the t-value calculated at 2,795 with a significance level of 0.006 so that it can be concluded that the second hypothesis which states there is a significant positive effect Promotion Mix to Customer satisfactionconsumer onPT. Indolok Bakti Utama Branch of Mataram unacceptable, This means thatmore interesting Promotion Mix then Customer satisfactionconsumers will increase in the use of the product padaPT. Indolok Bakti Utama Branch of Mataram.

In this research, promotion mix is reflected in the advertising, sales promotion, public relations, and personal sellingyang done by. Indolok Bakti Utama Branch of Mataram. The results support the results of research conducted by Faradina and Satrio (2016), Setiawan (2014), Adolfina, and Ruusen (2014), Tjahjaningsih (2013) where the promotion of positive effect on customer 
satisfaction. Similarly, empirical research conducted by Zain (2013) where the promotion is the variable that most dominant influence on the formation of the Customer Satisfaction. However, these results differ from the results Lenzun, Massie, Adare, 2014 where the results of research show promotion but not significant negative effect on customer satisfaction.

According Tijptono (2008: 219) is the promotion of the company's marketing activities to disseminate information, influence or persuade, and remind the target market for the company and its products to be willing to accept, buy and loyal to the products offered by the company that bersangkutan.Sementara In the opinion of Kotler and Keller (2009: 172) promotion is the means by which the company seeks to inform, persuade and remind consumers directly or indirectly on the products and brands sold.

\section{c. Client Service Quality Impact Customer satisfaction}

The results of hypothesis testing Services Quality variable indicates the value thitung4915with a significance level of 0.000 so that it can be concluded that there is a significant positive effect on the Quality of Service Customer satisfaction consumer onPT. Indolok Bakti Utama Branch of Mataram, This means thatthe higher it is Service qualitythen the higher or even very satisfied anyway dalammenggunakanproduk Customer Satisfaction at PT. Indolok Bakti Utama Branch of Mataram. Thus the second hypothesis proposed is acceptable.

The results support the research conducted by Faradina and Satrio 2016, Setiawan, 2014, Zain, (2013), Karuntu, Christoffel, Nia, (2014), Ogi, Adolfina, and Ruusen, (2014),Sivadas and Baker-Prewitt, 2000 (in Nam, Ekinci and Whyatt, 2011) where the quality of service has a positive relationship with satisfaction pelanggan.Demikian well as empirical studies conducted by Sureshchandar et al., (2002) that there is a very close correlation between the quality pelanggan.Pelanggan service and satisfaction will be satisfied if they get good service or as expected. But the results of different studies indicated by Ekinci and Whyatt, (2011), in his study shows that for consumer involvement with the category of services will occur more dominant in their influence on brand loyalty than satisfaction with the preferred brand.

In this research service quality is reflected in the five indicators, namely: Tangible, Reliability, Responsiveness, Empathy Assurancedan a portrait of quality of service at PT. Indolok Bakti Utama Branch of Mataram. of the five indicators stretcher indicators of reliability and empathy has very high responyang from survey respondents. Reliability in haliniberkaitan with ready or not Companies in providing the promised service immediately and satisfactorilycustomers conducted by PT. Indolok Bakti Utama Branch of Mataram. While empathy with regard to whether or not the staff friendly when communicating information about the product on the PT. Indolok Bakti Utama Branch of Mataram to its customers

\section{CONCLUSIONS AND RECOMMENDATIONS}

\subsection{Conclusion}

Based on the analysis of the results and discussion undertaken on the Influence Brand In Trust, Promotion Mix and Quality of Service, to satisfaction Pelangganpada PT. Indolok Bakti Utama Branch of Mataram some conclusions can be drawn as follows:

1. Brand In Trust has a positive and significant impact on customer satisfaction. This means that the higher the Brand In Trust will effect on higher the customer satisfaction of consumers.

2. Promotion Mix has a positive and significant impact on customer satisfaction. That is more interesting Promotion Mix consumers will increasingly the Customer Satisfaction.

3. Service quality has a positive and significant impact on customer satisfaction. The meaning that the higher value of Service quality will effect to higher value of the customer satisfaction at PT. Indolok Bakti Utama Branch of Mataram.

\subsection{Suggestions}

Based on the research results and conclusions that have been put forward this research have practical implications and limitations of the study as follows:

\subsubsection{Practical implications}

Based on descriptive analysis of variables that can be on the way down suggestions for PT. Indolok Bakti Utama Branch of Mataram as follows:

1. Further enhance Service Quality mainly on tangible aspects. So that consumers feel again the benefits of the products marketed by PT. Indolok Bakti Utama Branch of Mataram.

2. Continue to enhance the sales promotion strategies mediated primarily through social advertising so that consumers are more aware of more products sold. Socially mediated through more effective advertising to attract consumers from all walks of life not only focuses on the self-employed. Because during the PT. Indolok Bakti Utama Branch of Mataram rely more on sales promotion through sales.

\subsubsection{Research limitations}

This study was only conducted at PT. Indolok Bakti Utama Branch of Mataram, for it should be further research to be examined at different research sites as well as researching other types of products. In addition, it is expected for the next researcher to further develop this research to add another variable in order to obtain a more diverse research results and contribute both theoretically and practically. 
1. Haryono N, Octavia R. 2014. Influence of Brand Image Analysis and Quality of Service on Consumer Satisfaction And Its Impact on Consumer Loyalty. Indept Journal, Vol.4. 1, 20-27

2. Imania L, Widayanto.2014.Pengaruh Experiental Brand Trust Marketing and Customer Satisfaction Through Purchase Decision (Case Study On Consumer Larrisaa Aesthetic Center Branch Panjaitan, Semarang). Journal of Business Administration, 1-9.

3. Koyong TF, Tumbel AJ, Sepang T J.2016. Effect of Customer Satisfaction Promotion Mix At Novotel Manado GOLF RESORT \& CONVENTION CENTER. EMBA Journal, Vol.4, No.2. 768-777

4. Kotler, Philip and Kevin L Keller. (2005). Marketing Management vol 1. Jakarta: Erland.

5. Marlina, S. 2018. Quality Impact Analysis Product, Promotion, Brand Trust and Purchase Decision Consumer Satisfaction Motorcycles Honda Vario. Batang University Scientific Journal Vol.18, No.1, 16-125

6. Prayoga, D W. 2017. Effect of Online Marketing Of Interest Buy Through Trust as an intervening variable (Study at Mataram University Students). Master of Management Journal. Vol. 1.No.2,1-20

7. Santi, A. 2018.Analisis Effect of Trust and Value Services Satisfaction of Students At the Institute for Education and Skills Kharisma Banjarmasin. Journal of Economics and Business Vol.11 No. 1.158 to 170

8. Tjiptono (2008) .Pengaruh Brand in Trust to Customer Satisfaction. Economic Journal. Vol 20, No. 4.

9. Susilo H, Haryono AT, Mukery. 2017. Analysis of Effect of Price, Quality of Service, Promotion and Trust Customer Satisfaction With Decree viewed as an intervening variable Bandungan At Hotel Amanda Hills. Business Journal UNPAND, 1-20

10. Have now, Uma. (2006). Research Methodology For Business, Book 1 (4th ed.). Jakarta: Four Salemba.

11. Selnes, Fred. (1993). An Examination of the Effect of Product Peformance on Brand Reputation, Satisfaction and Loyalty, European Journal of Marketing, 27, 9: 19-35.

12. Sugiyono. (2013). Management Research Methods. Bandung: Alfabeta.

13. Supranto, J. and Limakrisna, (2007). Consumer Behavior and Business Strategy Competition Winning PemasaranuntukPartner Media Discourse, Jakarta

14. Zain, T, D. 2013. Effect of Service Quality, Promotion, Brand Trust in Customer Satisfaction. Journal Etikonomi, 1-14 